\title{
Semi-selective culture medium for Exserohilum turcicum isolation from corn seeds
}

\author{
Roberto Luis De Rossi ${ }^{1}$ e Erlei Melo Reis ${ }^{2}$
}

${ }^{1}$ Universidade Católica de Cordoba, Cordoba, AR; ${ }^{2}$ Universidade de Passo Fundo, Passo Fundo, RS, Bolsista do CNPq. Endereço atual OR Melhoramento de sementes Ltda, Passo Fundo, RS.

Autor para correspondência: Erlei Melo Reis (erleireis@upf.br)

Data de chegada: 02/09/2013. Aceito para publicação em: 09/06/2014 .

$10.1590 / 0100-5405 / 1925$

\section{ABSTRACT}

De Rossi, R. L.; Reis, E. M. De Rossi, R. L.; Reis, E. M. Semi-selective culture medium for Exserohilum turcicum isolation from corn seeds. Summa Phytopathologica, v.40, n.2, p.163-167, 2014.

Northern corn leaf blight, caused by Exserohilum turcicum (Et), is a disease of widespread occurrence in regions where corn, sweetcorn and popcorn are grown. This disease has great potential to cause damage and has been studied for years, but the association of its causal agent with seeds remains unconfirmed. Thus, the availability of a sensitive method to detect and quantify the inoculum in seeds, even at low incidence, is essential. The aim of this study was to develop a method to detect and quantify the presence of the fungus infecting and infesting corn and popcorn seeds. Artificially and naturally infected seeds were employed to develop the medium. The semi-selective medium was composed of carbendazim (active ingredient)
$(60 \mathrm{mg} / \mathrm{L})$, captan $(30 \mathrm{mg} / \mathrm{L})$, streptomycin sulfate $(500 \mathrm{mg} / \mathrm{L})$ and neomycin sulfate $(600 \mathrm{mg} / \mathrm{L})$ aggregated to the medium lactose casein hydrolysate agar medium. By using this, Et was detected in naturally infected corn seeds, showing $0.124 \%$ incidence, in four out of ten analyzed samples. In addition, 1.04 conidia were detected per infested seed. By means of isolation, pathogenicity test, morphological characterization and comparison with descriptions of the species in the literature, the fungus isolated from the seeds was confirmed to be $E t$. Both infection and infestation were considered low; thus, for studies of $E t$ detection in corn seeds, the use of semi-selective medium and more than 1,200 seeds/sample is suggested.

Additional keywords: Northern corn leaf blight, Helminthosporium turcicum, seed health, Zea mays.

\section{RESUMO}

De Rossi, R. L.; Reis, E. M. Meio de cultura semisseletivo para o isolamento de Exserohilum turcicumde sementes de milho. Summa Phytopathologica, v.40, n.2, p.163-167, 2014.

A helmintosporiose do milho, causada por Exserohilum turcicum (Et), é uma doença de ocorrência generalizada nas regiões produtoras de milho, milho doce e milho-pipoca. Trata-se de uma doença com alto potencial de danos e há muitos anos estudada, mas ainda sem a confirmação da associação do agente causal com sementes. Devido a esse fato, é fundamental a disponibilidade de método sensível para detectar e quantificar o inóculo em sementes, mesmo com incidência baixa. O objetivo desse trabalho foi desenvolver um método para detectar e quantificar a presença do fungo infectando e infestando sementes de milho e de milho-pipoca. Utilizaram-se sementes artificial e naturalmente infectadas no desenvolvimento do meio. O meio semisseletivo foi composto decarbendazim (ingrediente ativo)
(60 mg/L), captana (30 mg/L), sulfato de estreptomicina ( $500 \mathrm{mg} / \mathrm{L})$ e sulfato de neomicina $(600 \mathrm{mg} / \mathrm{L})$, agregados ao meio de lactose caseína hidrolisada ágar. Com esse meio detectou-se $E t$ em sementes de milho infectadas naturalmente com $0,124 \%$ de incidência, em quatro amostras de dez analisadas. Determinou-se, também, 1,04 conídio por semente de milho infestada. Mediante isolamento, prova de patogenicidade, caracterização morfológica e pela comparação com descrições da espécie na literatura, confirmou-se que o fungo isolado das sementes foi $E t$. Tanto a infecção como a infestação foram consideradas baixas, por isso, sugere-se em trabalhos de detecção de $E t$ em sementes de milho, usar meio semisseletivo e mais de 1.200 sementes/amostra.

Palavras-chave adicionais: Helmintosporiose, Helminthosporium turcicum, sanidade de sementes, Zea mays.

Northern corn leaf blight (NCLB), caused by Exserohilum turcicum (Pass.) Leonard \& Suggs, is a disease of widespread occurrence in all regions where susceptible corn, sweet corn and popcorn are grown. Green leaf area damaged during grain filling can cause up to $50 \%$ reduction in grain yield for susceptible hybrids $(18,30)$.

According to Maude (14), necrotrophic plant leaf pathogens survive in and are spread by infected seeds. There are reports of the introduction of necrotrophics into cultivated areas through infected seeds $(16,19,20$, 28 ). Smith (24) has reported that the seedborne inoculum is involved in the transportation and dissemination of plant species from their center of origin to the sites where host plants are grown.

Exserohilum turcicum (Et) has been reported as a seedborne pathogen, although there are no data on seed incidence and transmission rate to support those statements. Boosalis et al. (3), Lipps \& Mills (10), Luttrel (12), and White (28) have described in detail NCLB cycle but made no mention of its presence in corn seeds.

CIMMYT's corn seed assay handbooks (27) and "Ministério da Agricultura" (4) made reference to the probable presence of $E t$ in corn seeds, what is supported by the text "Identification of Drechslera species in seeds" written by Chidambaram et al. (5), who reported Drechslera turcica (synonymous of $E t$ ) in corn seeds and in other plant species based on the fungus presence in Sorghum bicolor (L.) Moench. and $S$. vulgare Pers. seeds, but not in corn.

Microorganisms associated with seeds can be detected by using 
different assays, but only a few allow the determination of a specific desired pathogen. Reliable data are still needed for transportation or dissemination, incidence and seed transmission of some important fungal pathogens. To fill this gap, sensitive specific methods for detection and quantification of seedborne inoculum are required (15).

A selective or semi-selective medium is a necessary tool to study the association between important fungal plant pathogens and seeds.

The principle of the selective medium is the exclusion of undesirable microorganisms that can restrict or completely inhibit the target fungus growth (25). A suitable substrate for fungal growth can be supplemented with chemicals that suppress the undesirable fungi and bacteria such as fungicides and antibiotics.

Under prevailing favorable weather, NCLB epidemics have been noticed to onset where corn hybrids susceptible to Et are grown.

Thus, we hypothesized that the fungus $E t$ can be introduced into the grown area by infected seeds. To confirm this hypothesis, a sensitive medium was required and this tool is not available yet to isolate $E t$ from corn seeds. The aim of this study was to develop a semi-selective medium to detect and quantify $E t$ in corn seeds.

\section{MATERIAL AND METHODS}

This study was carried out at the Laboratory of Plant Pathology - Mycology, Faculty of Agronomy, University of Passo Fundo (RS), during 2011 and 2012.

Seed inoculation. To detect and quantify $E t$ incidence, seeds of $\mathrm{P} 1630 \mathrm{H}$ and Celeron corn hybrids were artificially inoculated. Seeds were previously soaked in water in a humid chamber to become soft and facilitate the fungus penetration. Seeds were distributed in acrylic crystal polystyrene boxes $(11 \times 11 \times 3.5 \mathrm{~cm}$ high) containing a nylon foam layer at the bottom ( $0.5 \mathrm{~cm}$ thick), covered with two layers of filter paper and saturated with sterile distilled water (SDW). They were then incubated at $25 \pm 2{ }^{\circ} \mathrm{C}$ in the dark for $10 \mathrm{~h}$. Soon after soaking, seeds were placed scutellum side down for $36-48 \mathrm{~h}$ in colonies of $E t$ isolate 02-AR aged 15 days on potato-dextrose-agar medium, removed and dried at $25 \pm 2{ }^{\circ} \mathrm{C}$ for $48 \mathrm{~h}$.

Culture media. (i) Reis' selective medium (22), (ii) lactose casein hydrolysate agar (27) (LCHA), and (iii) semi-selective De Rossi \& Reis (DRR) were tested. Reis is used to isolate fungi showing dark mycelium like Bipolaris and Drechslera, while LCHA is used to enhance $E t$ sporulation.

Several chemicals were previously tested and added to LCHA, like carbendazim and captan fungicides, as well as the bacteriocids streptomycin sulfate and neomycin sulfate, to inhibit undesirable fungi and bacteria. Several combinations and concentrations of antimicrobial chemicals were supplemented to LCHA until the proposed medium (DRR) was selected.

The media Reis (22) and LCHA (27) were prepared according to their protocols.

Artificially inoculated seeds had their surface disinfested with aqueous sodium hypochlorite $(1 \% \mathrm{v} / \mathrm{v})$ for three minutes and rinsed with DSW for three times to remove hypochlorite residues. Seeds were plated in acrylic boxes and incubated at $25^{ \pm} 2^{\circ} \mathrm{C}, 12 \mathrm{~h}$ photoperiod, on shelves containing three $40 \mathrm{~W}$ fluorescent lamps at $50 \mathrm{~cm}$ above the boxes, for 10 days.

Experimental units consisted of 25 seeds per box and four replicates in a completely randomized design. Each experiment was repeated three times, totaling 300 seeds per treatment.
The presence of Et conidiophores and conidia on the seed was assessed under a stereomicroscope at 50x magnification after 10 days of incubation. Data were subjected to analysis of variance and means were compared according to Turkey's test at 5\% likelihood.

Detection and quantification of Exserohilum turcicum natural infection in corn and popcorn seeds. Commercial samples of corn seeds AG 8011 YG, Celeron TL, DKB 390, Exp 3949, P1630 H and P32R22 (Passo Fundo), P1630 H (Erechim) and three samples of popcorn Pipoca I (P625), Pipoca II and Pipoca III (Passo Fundo) were analyzed for $E t$ infection.

Five methods were tested: i) freezing filter paper (11), ii) potato dextrose agar (PDA), iii) Reis' medium (22), iv) lactose casein hydrolysate agar (LCHA) (27), and iv) semi-selective DRR.

Before plating, seeds had their surface sterilized by immersion in aqueous sodium hypochlorite $1.4 \%$ for three minutes, then washed three times in sterile distilled water to remove the residual hypochlorite.

For the freezing method (i), one hundred seeds were placed individually on two layers of filter paper moistened with SDW, spaced at $1-2 \mathrm{~cm}$ from one another, inside acrylic boxes. The boxes were kept for 24 hours in a growth chamber at a temperature of $25 \pm 2^{\circ} \mathrm{C}$ and $12 \mathrm{~h}$ photoperiod on shelves containing three $40 \mathrm{~W}$ fluorescent tubes located at $50 \mathrm{~cm}$ above the boxes. Then, they were placed in a freezer at -20 ${ }^{\circ} \mathrm{C}$ for $24 \mathrm{~h}$ and returned to the growth chamber for further seven days.

For the agar medium methods (ii, iii, iv, and v), seeds were plated with sterile tweezers and distributed equidistantly, 25 seeds/box. Seeds were incubated in a growth chamber at $25{ }^{ \pm} 2^{\circ} \mathrm{C}$ and $12 \mathrm{~h}$ photoperiod on shelves containing three $40 \mathrm{~W}$ fluorescent tubes located at $50 \mathrm{~cm}$ above the boxes, for 10 days.

Four replicates of 100 seeds per treatment, totaling 400 seeds, were used. Experimental design was completely randomized. Each test was repeated three times, totaling 1,200 seeds per treatment.

After 10 days of incubation, assessment was performed under a binocular stereomicroscope $(50 \mathrm{x})$. A seed was considered infected when $E t$ conidiophores and conidia were present.

The final experiment was performed after several preliminary tests to select the most sensitive method for natural detection of $E t$ in seeds.

All seeds infected with Et were transferred to Petri dishes containing LCHA medium to induce sporulation and confirm the causal agent identification. The plates were incubated in a controlled environment for 15 days; then, the fungal young colonies were transferred to test tubes containing PDA and kept in the refrigerator at $5^{\circ} \mathrm{C}$ for future pathogenicity test.

Conidial morphology measurements were performed after assembling individual microscope slide with fungal isolates from infected seeds. Length, width and number of septa/50 conidia per slide were determined under an optical microscope (400x), observing four replicates.

Seed germination was also assessed in this experiment.

Proof of pathogenicity. Six seeds of hybrid Pioneer P1630 H, known for its susceptibility to $E t$, were sown in plastic pots containing $2 \mathrm{~kg}$ of substrate. After emergence, seedlings were reduced to three per container and were kept in a greenhouse at $25+2^{\circ} \mathrm{C}$ and $12 \mathrm{~h}$ photoperiod.

Inoculum multiplication. Small colony portions from each $E t$ isolate were transferred to Petri dishes containing LCHA. The plates were sealed with PVC film and taken to a climatic chamber at $25 \pm$ $2^{\circ} \mathrm{C}$, in the dark, for 15 days, until abundant sporulation.

Inoculation of plants. Inoculation was performed by depositing $0.5 \mathrm{~mL}$ of inoculum $\left(5 \times 10^{4}\right.$ conidia $\left./ \mathrm{mL}\right)$ on the whorl of 
seedlings at growth stage V4 (22). The surfactant polyoxyethylene sorbitan monolaurate (Tween 20, Sigma Chemical Co.) was added at one drop/L water to the spore suspension to improve leaf wetting. For the control treatment, only water plus surfactant was poured.

Four replicates of each fungal isolate obtained from seeds were used, and each experimental unit was composed of a pot containing three plants. Plants were kept in a greenhouse at $25 \pm 2^{\circ} \mathrm{C}$ and $12 \mathrm{~h}$ photoperiod after inoculation.

Fungal reisolation. To complete the pathogenicity proof, fungal reisolation was performed from leaves showing symptoms of NCLB. Previously, leaf disc cuts containing part of the infected tissue were disinfested in aqueous sodium hypochlorite $1.4 \%$ for three minutes, and then rinsed with distilled water, removing the desinfestant residue. Leaf discs were distributed in a box containing polyethylene foam ( $5 \mathrm{~mm}$ thick) at the bottom and two sheets of filter paper on the top. The absorbent material was soaked with SDW until foam saturation, providing a moist environment, and maintained in a growth chamber at $25{ }^{ \pm} 2^{\circ} \mathrm{C}$ and $12 \mathrm{~h}$ photoperiod. After two days of incubation, the presence of $E t$ was searched under a stereoscopic microscope. Conidia were removed and transferred to Petri dishes containing DRR and their morphology was assessed after two weeks.

Detection and quantification of $\boldsymbol{E} \boldsymbol{t}$ seed infestation. A sample of corn seeds of hybrid P1630 was collected in a field showing symptoms of NCLB in the 2011/12 season, located in Erechim County, RS, and analyzed.

Detection of Et spores adhered to the surface of seeds was done by adopting the seed washing method, according to Brazil (4). Five samples of $50 \mathrm{~g}$ seed were introduced into a $250 \mathrm{ml}$-volume Erlenmeyer containing $50 \mathrm{ml}$ of SDW plus a drop of surfactant polyoxyethylene sorbitan monolaurate/L water and manually shaken for five minutes. The liquid was separated from the seeds by using a percolator. The suspension was allocated to five test tubes containing $10-\mathrm{ml}$ aliquots each and centrifuged (centrifuge Alpha II) for ten minutes at 3,000 $\mathrm{rpm}$. The supernatant was removed with a pipette, and the precipitate was left. SDW $(1 \mathrm{~mL})$ was added to each tube and shaken to resuspend the precipitate. The five tubes had their suspension transferred to one single tube with a final volume of $5.0 \mathrm{~mL}$. By using a micropipette, a volume of $10-\mu \mathrm{L}$ drop was poured on a microscope slide and spores were counted under an optical microscope. Five drops per sample were analyzed. Data were expressed as number of $E t$ conidia per seed.

Morphological characterization of $\boldsymbol{E t}$ present on seeds. Et was isolated from all infected seeds. For the isolation, $350 \mu \mathrm{L}$ conidial suspension, removed from the seeds by washing, were transferred to Petri dishes containing DRR. By using a Drigalsky handle, the spore suspension was streaked homogeneously on the medium surface and incubated at $25+2{ }^{\circ} \mathrm{C}$ in the dark for 15 days; subsequently, part of the fungus colony was transferred to test tubes containing potato dextrose agar (PDA) and stored at $5^{\circ} \mathrm{C}$.

Length, width and number of septa per 50 conidia per slide were determined under an optical microscope, at $400 \mathrm{x}$ magnification, observing four replicates.

Pathogenicity proof. For this test, the used methodology was previously described.

\section{RESULTS AND DISCUSSION}

Semi-selective medium for Exserohilum turcicum. The medium selected for Et detection in corn seeds consists of the following concentrations in $\mathrm{mg} / \mathrm{L}$ : carbendazim 60 , captan 30 , neomycin sulfate 600 and streptomycin sulfate 500, added to LCHA medium. It was called De Rossi \& Reis semi-selective medium (DRR).

DRR was most sensitive for detecting $E t$ in artificially inoculated corn seeds (Table 1).

The media LCHA and Reis were also suitable for the fungus detection in artificially infected seeds but showed significantly lower values than DRR. Contaminants were present, impairing the evaluation in LCHA. For Reis, longer time was demanded to detect $E t$; Reis needed 15 days while LCHA or DRR needed 10 days. Detection in a short time for LCHA medium (base medium for DRR) can be explained because it stimulates Et sporulation (27).

No comparison was made between hybrids for mean incidence because the latter is dependent on inherent characteristics of the hybrids (seed hardness and composition, required soaking time, etc.), which determines different percentages of incidence, mean $18.3 \%$ for Celeron and $57.6 \%$ for P1630.

Et showed better development in LCHA and DRR when incubated in the dark (data not shown). Therefore, for studies aimed at $E t$ detection in seeds, incubation in the dark is suggested.

Detection and quantification of Exserohilum turcicum natural infection in corn and popcorn seeds. Et natural infection in corn and popcorn seeds was confirmed by morphological characterization and pathogenicity proof (Table 2 ).

The freezing method and PDA, routinely used in seed health analysis, were not sensitive enough to detect the fungus. Therefore, the difficulty to detect $E t$ and the absence of data on its occurrence in corn seeds may be explained by the unavailability of a semi-selective medium. Reis' medium, used to isolate the dark-walled fungi Bipolaris

Table 1. Incidence of Exserohilum turcicum and seed germination for two hybrids of corn seeds that were artificially inoculated and plated on three media.

\begin{tabular}{|c|c|c|c|c|c|}
\hline \multirow[b]{3}{*}{ Medium } & \multicolumn{5}{|c|}{ Hybrid } \\
\hline & \multicolumn{2}{|c|}{ Celeron } & \multicolumn{2}{|c|}{ P1630 } & \multirow[b]{2}{*}{$\begin{array}{c}\text { Mean incidence } \\
(\%)\end{array}$} \\
\hline & $\begin{array}{c}\text { Incidence } \\
(\%)\end{array}$ & $\begin{array}{c}\text { Germination } \\
(\%)\end{array}$ & $\begin{array}{c}\text { Incidence } \\
(\%)\end{array}$ & $\begin{array}{c}\text { Germination } \\
(\%)\end{array}$ & \\
\hline LCHA & $7 b$ & $73 a$ & $54 b$ & $88 \mathrm{a}$ & 30.5 \\
\hline DRR & $26 a$ & $85 a$ & $88 \mathrm{a}$ & $77 \mathrm{ab}$ & 57.0 \\
\hline Reis & $22 a$ & $85 a$ & $34 b$ & $65 b$ & 28.0 \\
\hline Mean & 18.3 & 81.0 & 58.7 & 76.7 & 38.5 \\
\hline $\mathrm{CV}(\%)$ & 35.8 & 12.5 & 15.6 & 12.7 & 15.0 \\
\hline
\end{tabular}

Each sample had four replicates of 25 seeds. Means of three repeated experiments, totaling 300 analyzed seeds. Means followed by the same letter do not differ according to Turkey's test at 5\%. LCHA - lactose casein hydrolizate agar; DRR - De Rossi and Reis semi-selective medium; Reis - Reis' semi-selective medium. 
(former genus Helminthosporium) and Drechslera (former genus Helminthosporium), similar to Et (former Helminthosporium genus) (1), was not as sensitive as DRR.

Detection was confirmed in LCHA, which is also suitable to stimulate Et sporulation, showing $0.016 \%$ mean incidence. However, DRR was most sensitive for detecting $E t$ in corn and popcorn seeds, showing an average of $0.12 \%$ incidence.

The highest incidence was found for PI630 (Erechim) hybrid: 0.92\% in DRR. Popcorn Exp 3949 and PI (P625) samples showed one infected seed out of 1,200 seeds, corresponding to $0.08 \%$ incidence. P1630 (Passo Fundo) sample showed $0.16 \%$ incidence (only two out of 1,200 analyzed seeds). LCHA allowed the detection of fungal infection for P1630 (Passo Fundo) and popcorn I (P625) samples, both showing $0.08 \%$ incidence.

Et seed incidence was very low $(0.08 \%$ to $0.92 \%)$. Even for samples in which it was detected, some replicates showed zero value. Such a low incidence could not be detected by employing the routinely used methods (blotter test, freezing method, and PDA) which are not sensitive enough. So far no reference has been found in the literature for the presence of $E t$ infecting corn seeds; this is probably due to the lack of a sensitive medium and to the need of a larger number of seeds.

CIMMYT's (29) manual for corn seed health analysis and MAPA (4) pointed out the likelihood of $E t$ presence in corn seeds, based on the text "Identification of Drechslera species in seeds" by Chidambaram et al. (5), who cited the presence of Drechslera turcica (synonym of E. turcicum) in corn and other species based on the presence of the pathogen in Sorghum bicolor (L.) Moench. and S. vulgare Pers. seeds, but not in corn, which is then a misleading information. In Pennsylvania (USA), Chilton (6) also reported the occurrence of Helminthosporium turcicum in glumes and seeds of Sorghum vulgare [Sorghum bicolor] var. sudanense [S. sudanense.] but did not cite corn.

ISTA (International Seed Testing Association) (14) recommends 400 seeds (four replicates of 100) to conduct seed health tests. This number of seeds may be insufficient to detect low incidence, when compared to our study, in which a three-fold larger quantity of seeds was tested $(3 \times 400=1,200)$ to obtain numerical values. Two important points are useful for $E t$ detection in corn seeds: use semi-selective medium and test more than 1,200 seeds/sample.
Similarly to $E t$ in corn, there are few reports on the low incidence of Septoria tritici Desm. and Septoria glycines Hemmi in wheat and soybean seeds, respectively. These fungi have been considered seedborne pathogens. According to Wiese (31), the fungus $S$. tritici is rarely transmitted by seeds. Nevertheless, in the literature, 0.3 to $1.3 \%$ incidence in wheat kernels was reported by Paul et. al (18). Recently, Consolo et al (7) used a molecular technique and also reported infection of $S$. tritici in wheat seeds. The scarcity or absence of supporting data is probably attributed to the low sensitivity of the used methods.

For corn, the same has happened with the gray leaf spot caused by Cercospora zeae-maydis Tehon \& Daniels. This pathogen has not yet been cited to infect corn seeds $(13,23)$.

The availability of sensitive methods is essential to detect and quantify the seedborne inoculum, even when the incidence is low. The NCLB $(E t)$ cycle has been detailed by Boosalis et al. (3), Lipps \& Mills (10), Luttrel (12), and White (30); nevertheless, those authors made no reference to whether the fungus was present or not in corn seeds.

Under dry weather, the period when this study was done, NCLB was not a disease showing high intensity in the region where samples were collected (Rio Grande do Sul). Moreover, a similar study conducted with samples from areas/seasons showing high disease intensity, such as Cordoba, Argentina, could indicate seed incidence higher than that of our study.

In the same region where our study was conducted, other researchers have not detected the presence of Et infecting corn seeds either (17). Their study was carried out without selective media/methods, assessing corn seed health in 224 samples.

Identification and characterization of the causal agent. Regarding morphological width and length measurements obtained for 200 conidia, spores measured 10.0 to $22.5 \times 47.5 \mu \mathrm{m}$ to $110.1 \mu \mathrm{m}$ and had 2-8 septa per conidium. Width and length measurements were close to those described by Ellis (9): 18-32 x 50-144 $\mu \mathrm{m}$, but differed for the number of septa, while Ellis cited 4-9 septa. According to Shurtleff (25), conidia measure 105 x $20 \mu \mathrm{m}$ and have between 3 - 8 septa. Shurtleff's values were closer to those determined in our study.

Pathogenicity. At one week after the pathogen inoculation in the seedling whorl of susceptible corn hybrid P1630, the first elongated leaf showed elliptical shape and gray-green colored lesions, similarly

Table 2.Exserohilum turcicum natural infection incidence (\%) in corn and popcorn seeds according to five detection methods.

\begin{tabular}{cccccc}
\hline & \multicolumn{3}{c}{ Method/Medium } & DRR \\
\cline { 2 - 5 } Sample & Freezing method & PDA & Reis & LCHA & 0 \\
\hline AG 8011 YG & 0 & 0 & 0 & 0 & 0 \\
Celeron TL & 0 & 0 & 0 & 0 & 0 \\
DKB 390 & 0 & 0 & 0 & 0 & 0.08 \\
Exp 3949 & 0 & 0 & 0 & 0 & 0.92 \\
P1630 (Erechim) & 0 & 0 & 0 & 0 & 0 \\
P1630 (Passo Fundo) & 0 & 0 & 0 & 0.08 & 0.08 \\
P32R22 & 0 & 0 & 0 & 0 & 0 \\
Popcorn I (P625) & 0 & 0 & 0 & 0.08 & 0 \\
Popcorn II (not identified) & 0 & 0 & 0 & 0 & 0.124 \\
Popcorn III (not identified) & 0 & 0 & 0 & 0 & 0.016 \\
\hline Mean & 0 & 0 & 0 &
\end{tabular}

Each sample with four replicates of 100 seeds. Means of three repeated experiments, totaling 1,200 seeds. PDA-potato dextrose agar; Reis - Reis> semi-selective medium; LCHA - lactose casein hydrolizate agar; DRR - De Rossi and Reis semi-selective medium 
to the description by Elliot \& Jenkins (8) and Bach\& Kimati (2). At 15-21 days, all inoculated plants showed typical symptoms of NCLB. The positive inoculations confirmed the pathogenicity of $E t$ isolates for all infected corn and popcorn seeds.

Detection and quantification of Exserohilum turcicum infestation in corn seeds. Conidia were detected infesting corn seeds at an average of 1.04 conidia per seed. The smallest number of conidia

Table 3. Exserohilum turcicum conidia detected on the seed surface of corn hybrid P1630.

\begin{tabular}{cccc}
\hline Replicate & $\begin{array}{c}\text { Conidia/10 } \boldsymbol{\mu L} \\
\text { water(no.) }\end{array}$ & $\begin{array}{c}\text { Seed/50 g } \\
\text { (no.) }\end{array}$ & $\begin{array}{c}\text { Conidia/seed } \\
\text { (no.) }\end{array}$ \\
\hline I & 0.56 & 193 & 1.16 \\
II & 0.56 & 190 & 1.17 \\
III & 0.68 & 203 & 1.33 \\
IV & 0.32 & 197 & 0.65 \\
V & 0.44 & 192 & 0.91 \\
\hline Mean & 0.51 & 195 & 1.04 \\
\hline
\end{tabular}

per grain was 0.65 and the largest one was 1.33 (Table 3).

DRR semi-selective medium was most sensitive for $E t$ detection in corn seeds. Our study confirms Et naturally infecting and infesting corn and popcorn seeds. The difficulties in detecting Et can be due to its low incidence and to the decreased sensitivity of methods routinely used in its detection.

Isolation, inoculation, morphological characterization and comparison with descriptions of the species in the literature confirmed that the fungus isolated from all infected/infested seeds belongs to the species $E t$, the causal agent of NCLB.

\section{REFERENCES}

1. Alcorn, J. L. The taxonomy of "helminthosporium" species. Annual Review of Phytopathology, Palo Alto, v.26, p. 37-56, 1988.

2. Bach, E. \& Kimati, H. Comparação morfológica e patogênica de Exserohilum turcicum, isolado de milho, sorgo e capim massambará. Summa Phytopathologica, Botucatu, v.21, p.134-139. 1995.

3. Boosalis, M.G., Summer, D.R. \& Rao, A.S. Overwintering of conidia of Helminthosporium turcicum on corn residues and in soil in Nebraska. Phytopathology, St. Paul, v. 57, p. 990-996. 1967.

4. Brasil. Ministério da Agricultura, Pecuária e Abastecimento. Manual de Análise Sanitária de Sementes/Brasília DF; MAPA/ACS, 2009. 200 p.

5. Chidambaram, P., Mathur, S.B.; Neergaard, P. Identification of seedborne Drechslera species.Friesia,Hornbæk, v. 10, p.165-207.,1973.

6. Chilton, S.J.P. The occurrence of Helminthosporium turcicum in the seed and glumes of sudan grass. Phytopathology, St. Paul, v. 30, n.6, p. $533-536,1940$.

7. Consolo,V. F.; C. M. Albani, C. M.; Berón,C. M.; G. L. Salerno,G. L.; C. A. Cordo, C. A. A conventional PCR technique to detect Septoria tritici in wheat seeds. Australasian Plant Pathology, Toowoomba, v. 38, n 3, p. 222-227, 2012.
8. Elliot, C.H.; Jenkins, M.T. Helminthosporium turcicum leaf blight of corn. Phytopathology, St. Paul, v.36, p. 660, 1946.

9. Ellis, M.B. Dematiaceous hyphomycetes. Kew, Surrey: CAB. 1971.608p.

10. Lipps, P.E \& Mills, D. Northern corn leaf blight. Ohio State University. 2002. Extension fact sheet 1087, OH-43210

11. LuccaFilho, O.A. Metodologia dos testes de sanidade de sementes In: Soave, J. \& WetzeL, M.M.V. da S. Patologia de sementes. Campinas; Fundação Cargill/Abrates, 1987.p. 276-298.

12. Luttrel, E.S. The perfect state of Helminthosporium turcicum, PhytopathologySt. Paul, v. 48, p. 281-287. 1958.

13. McGee, D. C. Maize diseases: a reference source for seed technologists. American Phytopathological Society, St. Paul, 1988.

14. Machado, J.C.; Langerak, C.J.; Jaccoud-Filho, D.S. Seed-borne fungi: a contribution to routine seed health analysis. ISTA, Copenhagen, $2002.134 \mathrm{p}$.

15. Maude, R.B. Achievements and objectives in research on seed-borne diseases of vegetables. In: Nasser, L.C., Wetzel, M.M.; Fernandes. J.M. (Ed.) Seed Pathology- International advanced course. Brasília, ABRATES, 1988, Part 4, p. 267-275.

16. Menten, J.O.M. Prejuízos causados por patógenos associados às sementes. In: Menten, J.O.M. Patógenos em sementes: detecção, danos e controle químico. São Paulo: Ciba Agro, 1995. p. 115 - 136.

17. Nerbass, F.R.; Casa, R.T.; Angelo, H.R. Sanidade de sementes de milho comercializadas na safra agrícola de 2006/07 em Santa Catarina e no Rio Grande do Sul. Ciências Agroveterinárias, Lages, v.7, n.1, p. 30-36, 2008.

18. Paul, Y.S.; Hunde, B.; Alemu, M.; Ayalew, M. Studies on seed-borne mycoflora of wheat in Ethiopia. In: TANNER, D.G. Developing sustainable wheat production systems. Addis Ababa, Ethiopia: CIMMYT, 1994.

19. Perkins, J.M.; Pedersen, W. L. Disease development and yield losses associated with northern leaf blight on corn. Plant Disease, St. Paul, v. 71, p. 940-943, 1987.

20. Pinto, N.F.J. Tratamento com fungicidas de sementes de milho. In: SOAVE, J., Oliveira, M.R.M.; Menten, J.O.M. (Ed.) Tratamento químico de sementes. Campinas: Fundação Cargil, 1996. p. 52-57.

21. Reis, E.M.; Casa, R.T. Manual de identificação e controle de doenças de milho. Passo Fundo: Aldeia Norte, 1996.

22. Reis, E.M. Selective medium for isolating Cochliobolus sativus from soil. Plant Disease, St. Paul, v. 67, p. 68-70, 1983.

23. Richardson, M. J. An annotated list of seed-borne diseases. 4th ed. International Seed Testing Association: Zurich, 1990.

24. Ritchie, S.W.; Hanway, J.J.; Benson, G.O. How a corn plant develops Ames: Iowa State University of Science and Technology, 1993.26p. Special Report, 48.

25. Shurtleff, M.C. Compendium of corn diseases. American Phytopathological Society:St. Paul, 1992. 105p.

26.Smith, B.D. The emergence of agriculture. Scientific American Library, n., p. New York, 1995.

27. Tsao, P.H. Selective media for isolation of pathogenic fungi. Annual Review of Phytopathology, Palo Alto, v. 8,p, 157-186., 1970.

28. Tuite, J. Plant pathological methods. Fungi and bacteria. Department of botany and plant pathology, Purdue University, 1969. 239p.

29. Warham, E.; Butler, L.D.; Sutton, B. C. Seed testing of maize and wheat. a laboratory guide. El Batán, International Maize and Wheat Improvement Center CIMMYT, 1996. 84p.

30. White, D.G. Compendium of corn diseases. $3^{\text {rd }}$ edition. The American Phytopathological Society: St. Paul, 1999. 78p.

31. Wiese, M.V. Compendium of wheat diseases. American Phytopathological Society, St. Paul, 1977.106p.

32. Zambolim, L.; Casa, R.T.; Reis, E.M. Sistema plantio direto e doenças em plantas. Fitopatologia Brasileira, Brasília, v. 25, p.585-595, 2000. 